\title{
Stimulus control of acquired fear and instrumental behavior'
}

RICHARO C. DEBOLD

WESLEYAN UNIVERSITY

Rats fear-conditioned in distinctive start-boxes and al lowed to escape to safe-boxes with opposite cues do not learn to hurdle jump, without shock, on subsequent days when the cues are reversed but do learn when the cues are reinstated. Other groups that, without shock, learn with the start-box cues the same, do not perform on subsequent days, when cues are reversed.

Recent theoretical statements have suggested that acquired fear is under the control of those stimulus cues which are present during fear conditioning (Brown, 1961; McAllister \& McAllister, 1965). In the usual paradigm, animals are shocked in a distinctive box and allowed to escape. On subsequent trials, with the shock no longer present, a test for the presence of fear involves requiring the animal to learn a new response to escape from the cues of the box in which they had been formerly shocked (Miller, 1951).

At first glance the logic seems simple, but it is possible to parcel the learning situation into two parts: the learning of the fear and learning the particular responses which escape the cues which arouse the fear. The present study was designed to test the hypothesis that the hurdle-box case does indeed involve two separate learning situations. To accomplish this test, the start and safe box cues were reversed from fear-conditioning days to test days and then reversed on subsequent days. We observed the stimulus conditions under which the hurdle jumping response was not learned even when obvious signs of fear occurred in the situation, indicating that two processes were taking place.

Method

Thirty-two hooded rats of the Long-Evans strain, approximately 90 days of age, were divided into four groups of eight. Each group received two days of 10 trials each of fear-conditioning using shock, and two days of 10 trials each of hurdle-jump training without shock. The apparatus was a modified Miller-Mowrer box of two compartments each 15 in. long, 7-1/2 in. wide and $7-1 / 2$ in. deep. Each side had grid floors and each side had two sets of insert-liners, one black and one white to permit radical changes in the cues. A barrier $1-1 / 2$ in. above the grids was installed as a hurdle on the two days of hurdle-jump training.

The start box was electrified using a Starrett "rat radar" constant power shock source of $1.5 \mathrm{ma}$. The timing mechanism of the box was started by the weight of the rat dropping in and was stopped by means of a hand switch. On each trial, each rat was dropped into the start box facing away from the center of the box. Time to escape was recorded, and the rat was allowed to remain on the right side of the box for 30 sec., unless it recrossed, in which case it was removed immediately. The rats were run one trial at a time in order until each rat completed 10 trials on each day. If a rat did not cross at all, he was removed from the apparatus after $2 \mathrm{~min}$. The time between trials for any one rat varied from 8 to $20 \mathrm{~min}$. Thus, from first to tenth trial took about $3 \mathrm{hr}$.

To control for stimulus intensity dynamism, the cues in the start box during fear-conditioning differed for each half of the animals. In addition, to demonstrate stimulus-control of the hurdle jumping response, on days 3 and 4 , the no-shock days, the cues in the situation were altered as shown in Table 1.

The noise was the clicking of the scrambler which was actually disconnected from the grid on days 3 and 4 . A soft cloth was placed over the start-box grid on the occasions marked "cloth over bars."

It can be seen that the design of the experiment provides two basic sequences of events.

Case. 1. Two days of fear-conditioning in which animals escape shock followed by one day of hurdle training in a radically different environment and then one day of hurdle-training in the same environment as for fear conditioning.

Case 2. Two days of fear-conditioning followed by one day of hurdle training in the same environment followed by one day of hurdle training in a radically different environment.

Table 1. Schedule of start-box cues for each group on each day of the experiment. The safe box, in every case, had the opposite cues.

\begin{tabular}{|c|c|c|c|c|}
\hline & \multicolumn{2}{|c|}{ Group $1(N=16)$} & \multicolumn{2}{|c|}{ Group $2(N=16)$} \\
\hline \multirow[t]{2}{*}{$\begin{array}{l}\text { Doy } 1 \\
\text { and } \\
\text { Doy } 2 \\
\text { (Fear } \\
\text { Conditioning }\end{array}$} & \multicolumn{2}{|c|}{$\begin{array}{l}\text { Shock on } \\
\text { Scrambler noise on } \\
\text { Lights off } \\
\text { Black sides } \\
\text { J Bars exposed (no cloth) }\end{array}$} & \multicolumn{2}{|c|}{$\begin{array}{l}\text { Shock on } \\
\text { Serambler noise on } \\
\text { Lights on } \\
\text { White sides } \\
\text { Bars exposed (no cloth) }\end{array}$} \\
\hline & $\begin{array}{l}\text { Group la } \\
(N=B)\end{array}$ & & & \\
\hline $\begin{array}{l}\text { ay } 3 \\
\text { urdle jump } \\
\text { earning } \\
\text { o shock }\end{array}$ & $\begin{array}{l}\text { Light off } \\
\text { Noise on } \\
\text { Black sides } \\
\text { Bars ex- } \\
\text { posed(Same) }\end{array}$ & $\begin{array}{l}\text { Light on } \\
\text { Noise off } \\
\text { White sides } \\
\text { Cloth over } \\
\text { ) bors(Changed) }\end{array}$ & $\begin{array}{l}\text { Lights on } \\
\text { Noise on } \\
\text { White Sides } \\
\text { Bars ex- } \\
\text { posed(Same) }\end{array}$ & $\begin{array}{l}\text { Light off } \\
\text { Noise off } \\
\text { Black sides } \\
\text { Cloth over } \\
\text { bars } \\
\text { (Chonged) }\end{array}$ \\
\hline $\begin{array}{l}\text { Day } 4 \\
\text { Hurdle jump } \\
\text { Learning } \\
\text { No shock }\end{array}$ & $\begin{array}{l}\text { Light on } \\
\text { Noise off } \\
\text { White sides } \\
\text { Cloth over } \\
\text { bars } \\
\text { (Changed) }\end{array}$ & $\begin{array}{l}\text { Light off } \\
\text { Noise on } \\
\text { Black sides } \\
\text { Bars exposed }\end{array}$ & $\begin{array}{l}\text { Light off } \\
\text { Noise off } \\
\text { Black sides } \\
\text { Cloth over } \\
\text { bars } \\
\text { (Changed) }\end{array}$ & $\begin{array}{l}\text { Lights on } \\
\text { Noise on } \\
\text { White sides } \\
\text { Bars exposed }\end{array}$ \\
\hline
\end{tabular}




\section{Results}

The most striking result was that animals seldom jumped the hurdle on those days when the start and safe box cues were reversed. This was true whether the change occurred on day 3 or day 4 . An analysis of variance on day 3 for mean time to cross the hurdle for changed versus same environment groups yielded $F=394.53, d f=1 / 28, p<.01$. For day 4 the same analysis gave $\mathrm{F}=133.07, \mathrm{df}=1 / 28, \mathrm{p}<.01$. There was no significant difference between groups fear-conditioned under low stimulus-intensity and high stimulus-intensity. For day $3 \mathrm{~F}=1.52, \mathrm{df}=1 / 28, \mathrm{p}=\mathrm{ns}$; for day 4 $\mathrm{F}=0.92$, df $=1 / 28, \mathrm{p}=\mathrm{ns}$.

There is habituation of the hurdle-jump on both days 3 and 4 for animals tested under the same condition. That is, the animals tend to slow down their escape times. An analysis of variance on escape times over trials for the "same-cue" condition for days 3 and 4 yields the following: The effect of days 3 vs. $4, F=0.94$, $\mathrm{df}=1 / 30$, ns; for Trials, $\mathrm{F}=4.025, \mathrm{df}=9 / 270, \mathrm{p}=<.01$. Discussion

These results suggest that the onset of fear is not a certain predictor of what an animal will actually do in a given situation. Observation of individual animals showed stretching and exploration and some attempts to push on the hurdle. Clearly the animals were active and agitated under the changed-cues conditions even though they did not cross the hurdle. Theoretical statements of the role of acquired fear must state what habits will be activated by the fear. The habits appropriate to the situation may be independent of the fear and under control of the same or different stimuli. In the present study, animals did not hurdle-jump after fear-conditioning, when cues were changed; then when the cues were reinstituted, they did hurdle jump. Since their behavior is clearly stimulus bound, even though they appear agitated in both conditions, the instrumental behavior may be conceived to be independent of the fear-response.

Since the safe-box cues are also reversed, it is possible to conceive of the animals avoiding the fear-inducing cues of the safe box when they are reversed. In such an analysis, the failure to learn to jump the hurdle indicates that the fear-response does occur and that the behavior depends on the cues of the environment not on the presence of fear alone. Again, the two responses are seen to be independent.

\section{References}

Brown, J. S. The motivation of behavior. New York: McGrawHill, 1961.

McAllister, W. R., \& McAllister, D. E. Variables influencing the conditioning and the measurement of acquired fear. In W. F. Prokasy (Ed.), Classical conditioning. New York: AppletonCentury-Crofts, 1965.

Miller, N. E. Learnable drives and rewards. In S. S. Stevens (Ed.), Handbook of experimental psychology. New York: John Wiley \& Sons, 1951.

Nofe

1. Supported by N. I. H. Grant MH08740-01.

\section{Comment on Atrens' "Vibration effect" 1}

\section{by Dale M. Atrens and Melvyn B. King}

A study by Atrens (1966) reported that rats placed on a vibrating floor for $1 \mathrm{hr}$. losta significantly $(\mathrm{p}<.01)$ greater amount of weight than control animals which were exposed to either $1 \mathrm{hr}$. of the sound accompanying vibration or were merely placed in the experimental chamber for $1 \mathrm{hr}$. with neither sound nor vibration. Since there were no significant differences among groups on the activity measure the author proposed a twofactor hypothesis to account for the weight losses. The first factor was a "real" vibration effect brought about by an induced increase in the rate of catabolism of the animals' fatty tissue. The second was a spurious effect resulting from intestinal and bladder evacuation due to the increased emotionality caused by this stressor stimulus.

To assess the value of the spurious effect and to increase the generality of the earlier data, the present authors replicated the original study in a new apparatus ${ }^{2}$ with a more precisely specified physical stimulus while controlling for evacuation. A spectographic analysis of the sound producedby the vibrating floor indicated the great majority of the recorded frequencies to be in the 1200-1300 cps range while the amplitude array indicated homogeneous displacements with the maximum total excursion not exceeding 1/16 in. To control for the evacuation factor all $30 \mathrm{Ss}$ were deprived of food and water for $24 \mathrm{hr}$. before the experimental session. The efficacy of this procedure is indicated by the fact that during the entire study $E$ observed no urination and only a few bolusses. The pattern of percentage weight losses here was virtually identical to that obtained in the first study only this time they were uniformly reduced by $0.5 \%$.

These data indicate that vibrated rats show a weight loss beyond that which can be accounted for by defecation and urination. However, this by no means contraindicates the possibility of a stress effect not unique to vibration. Just what proportion of the weightloss is due to a "real vibration effect" remains to be determined.

\section{Reference}

Atrens, D. M. J. P. The effect of cutaneous vibration on weight loss. Psychon. Sci., 1966, 4, 281-282.

\section{Notes}

1. Presented at SEPA, New Orleans, March, 1966.

2. Complete specifications of the apparatus will be provided on request. 